\title{
MODEL PENDUGA VOLUME POHON WERU (Albizia procera (Roxb.) Benth.) DI KABUPATEN MAJALENGKA - JAWA BARAT
}

\author{
Tree Volume Model of Weru (Albizia procera (Roxb.) Benth.) in Majalengka West Java \\ Sofwan Bustomi dan/and Mira Yulianti \\ Pusat Penelitian dan Pengembangan Peningkatan Produktivitas Hutan \\ Kampus Balitbang Kehutanan, Jl. Gunung Batu No. 5 Po.Box 331, Bogor 16118 \\ Telp. 0251-8631238, Faks. 0251-7520005
}

Naskah masuk : 25 Februari 2013; Naskah diterima : 10 Februari 2014

\begin{abstract}
Weru tree is one of species has been widely developed in private forests. The purpose of this study was to estimate volume of weru in Majalengka with most realible model. Trees volume of existing weru stands of different diameter classes were measured using purposive sampling method. Data were analyzed with five regression equations with trees breast height diameter and height as independent variables. The best model was categorized based on analysis of maximum determination coefficient $\left(R^{2}\right)$, minimum bias and root mean square error (RMSE). The result showed that the best model of prediction equations of volume was $\mathrm{Ln} \mathrm{V}=-7.59+2.02 \ln \mathrm{D}$ with $S A 0.0165$ and SR 0.1178.
\end{abstract}

Keywords: Tree volume estimation model, weru, diameter, height of tree

\begin{abstract}
ABSTRAK
Pohon weru banyak dibudidayakan sebagai salah satu tanaman penghasil kayu pertukangan dan energi yang dikembangkan di masyarakat khususnya pada hutan rakyat. Tujuan penelitian ini adalah untuk melakukan penyusunan model penduga volume pohon yang memiliki ketelitian tinggi untuk jenis Weru di Kabupaten Majalengka. Data dikumpulkan dengan mengukur volume pohon pada berbagai kelas diameter pada tegakan Weru yang sudah ada dengan metode purposive sampling. Selanjutnya data dianalisis menggunakan lima persamaan regresi penyusun model berdasarkan peubah bebas diameter setinggi dada dan tinggi pohon. Pemilihan model terbaik didasarkan pada hasil penghitungan nilai koefisien determinasi maksimum $\left(\mathrm{R}^{2}\right)$, bias minimum dan Root mean square error (RMSE) terkecil. Hasil penelitian menunjukkan bahwa model persamaan pendugaan volume terbaik yaitu $\mathrm{Ln} \mathrm{V}=-7,59+2,02 \ln \mathrm{D}$ dengan SA 0,0165 dan SR 0,1178.
\end{abstract}

Kata kunci: Model penduga volume, weru, diameter, tinggi pohon

\section{PENDAHULUAN}

Weru (Albizia procera (Roxb.) Benth.) banyak dimanfaatkan sebagai kayu bakar, kayu bangunan, pakan ternak, pagar hidup, tali dari kulit kayunya (Jarunadi, 2013). Oleh karenanya weru atau disebut juga Kihiang dipilih sebagai salah satu tanaman penghasil kayu energi (Bustomi, 2010). Keunggulan weru sebagai kayu energi antara lain karena jenis weru memiliki karakter cepat tumbuh, tahan kering, bisa dipangkas "coppies" dan memiliki daya kalor yang tinggi yaitu $4.865 \mathrm{kalori} / \mathrm{gram}$. Disamping itu tanaman ini mudah dibudidayakan karena memiliki proses hidup yang baik dan pertumbuhan awal yang cepat dan secara luas dibudidayakan dalam sistem agroforestri (Orwa et al., 2009) sehingga jenis tanaman ini sangat mudah ditemukan di masyarakat.

Sampai saat ini, produktivitas weru hasil budidaya masyarakat belum diketahui dengan pasti, sehingga ketika melakukan pemanenan dan dijual dalam bentuk tegakan berdiri maka harga kayu ditentukan sepihak oleh pembeli (tengkulak). Agar masyarakat mempunyai pengetahuan akan potensi weru yang dimilikinya perlu dibantu dengan alat pendugaan volume yang praktis dan akurat. Dengan pengetahuan tersebut diharapkan masyarakat memiliki posisi tawar yang lebih baik.

Persamaan yang umum digunakan untuk menduga volume pohon antara lain adalah model persamaan regresi, yang penyeleksiannya melalui pendekatan metode kuadrat terkecil (OLS : 
Ordinary Least Square) (Brandies et al., 2006). Metode 'pendekatan' ini secara statistik merupakan teknik sangat penting untuk regresi ataupun analisis sesatan dalam validasi, seringkali digunakan untuk penyelesaian problematik yang melibatkan kumpulan data yang tersusun secara acak. Hal lain, karena dalam menduga sering dihadapkan pada ragam kondisi lapangan sehingga kemungkinan akan terjadi bias yang tinggi, maka untuk pendugaan hasil tegakan memerlukan metode yang akurat, efisien dan handal (Arevalo et al., 2007).

Tujuan penelitian ini adalah untuk penyusunan model penduga volume pohon jenis weru di hutan rakyat di Kabupaten Majalengka. Model ini diharapkan dapat membantu masyarakat mengelola hutan rakyat untuk menduga volume pohon yang masih berdiri.

\section{METODOLOGI}

\section{A. Lokasi Penelitian}

Kegiatan penelitian dilakukan di hutan rakyat Desa Babakan Jawa, Kecamatan Majalengka, Kabupaten Majalengka, Provinsi Jawa Barat. Secara geografis lokasi penelitian terletak pada $108^{\circ} 13^{\prime} 51$ "BT $06^{\circ} 50^{\prime} 37$ "LS pada ketinggian 25-37,5 $\mathrm{m}$ di atas permukaan laut (dpl) termasuk dalam tipe iklim B dengan curah hujan rata rata 2.400-3.800 mm/tahun dan rata rata hari hujan 16 hari per bulan, ketinggian tempat $8-857 \mathrm{~m} \mathrm{dpl}$ dan suhu $18,8-37,0^{\circ} \mathrm{C}$ (BPS, 2010).

\section{B. Teknik Pengumpulan Data}

Pengumpulan Data dilakukan dengan penarikan contoh terarah (purposive sampling) menurut kelas diameter dengan banyaknya contoh mewakili berbagai kelas diameter yang telah ditentukan. Persyaratan pohon contoh adalah bentuk batangnya normal, sehat atau tidak berpenyakit.

Penyusunan dan validasi model penduga volume pohon menggunakan 47 pohon. Dengan jumlah contoh yang dikumpulkan untuk menyusun model penduga volume sebanyak 35 pohon, sedangkan untuk keperluan validasi dikumpulkan 12 pohon independen. Secara umum, pohonpohon contoh mempunyai rataan standar deviasi yakni diameter $(\mathrm{cm}): 36,4 \pm 19,07$ dan tinggi (m): $14,8 \pm 1,8$. Adapun tabel frekuensi data disajikan pada tabel 1 .

Tabel (Table) 1. Frekuensi pohon model berdasarkan kelas diameter (Frequency of tree model based on diameter class)

\begin{tabular}{ccccc}
\hline & $\begin{array}{c}\text { Kelas Diameter } \\
\text { No }\end{array}$ & \multicolumn{3}{c}{ Pohon Model (Models of tree) } \\
\cline { 3 - 5 }$(\mathrm{cm})$ & $>10,5$ & $\begin{array}{c}\text { Total } \\
(\text { Total })\end{array}$ & $\begin{array}{c}\text { Penyusunan } \\
\text { (Composing) }\end{array}$ & $\begin{array}{c}\text { Validasi } \\
\text { (Validation) }\end{array}$ \\
\hline 1 & $10,5-20,5$ & 11 & 1 & 1 \\
2 & $20,5-30,5$ & 16 & 9 & 2 \\
3 & $30,5-40,5$ & 7 & 12 & 4 \\
4 & $40,5-50,5$ & 1 & 5 & 2 \\
5 & $50,5-60,5$ & 3 & 1 & 1 \\
6 & $60,5-70,5$ & 2 & 1 & 1 \\
7 & $70,5-80,5$ & 2 & 1 & \\
8 & $80,5-90,5$ & 1 & 1 & \\
9 & $90,5-100,5$ & 1 & 1 & \\
10 & $100,5-110,5$ & & & \\
11 & $110,5-120,5$ & 1 & 35 & \\
12 & Jumlah & 47 & & \\
\hline
\end{tabular}




\section{Pengukuran Pohon Contoh}

Parameter yang diukur dari setiap pohon contoh adalah diameter setinggi dada, diameter per seksi dengan panjang tiap seksi 1 meter dan tinggi pohon. Untuk tiap contoh dilakukan pengukuran seksi (section wise measurement) diameter pangkal dan ujung baik batang maupun cabang dengan panjang seksi masing-masing $1 \mathrm{~m}$ sampai dengan diameter terkecil sebesar $7 \mathrm{~cm}$.

Untuk keperluan penghitungan volume, maka tiap pohon contoh dibagi-bagi ke dalam seksiseksi batang selanjutnya tiap seksi batang diukur diameter pangkal dan ujungnya untuk menghitung volumenya dengan menggunakan rumus smalian (Chapman \& Meyer, 1949).

\section{Analisis Data}

\section{Analisis hubungan diameter tinggi}

Secara geometrik volume pohon tersusun dari komponen bidang dasar (dicirikan oleh diameter) dan tinggi pohon. Oleh karena itu, apabila akan menduga volume hanya digunakan (diwakili) oleh diameter saja maka keperwakilan diameter tersebut harus didasarkan atas hipotesis adanya hubungan (korelasi) kuat antara tinggi dan diameter itu sendiri. Koefisien korelasi (r) berdasarkan data contoh berupa hubungan antara tinggi dan diameter dapat dihitung dengan menggunakan rumus yang dikembangkan oleh Karl Pearson, yaitu (Abdurrahman et al., 2012):

$$
r=\frac{\sum_{i=1}^{n} x_{i} y_{i}-\left(\sum_{i=1}^{n} x_{i}\right)\left(\sum_{i=1}^{n} y_{i}\right)}{\sqrt{\left[\sum_{i=1}^{n} x^{2}{ }_{i}-\left(\sum_{i=1}^{n} x_{i}\right)^{2}\right]}\left[\sum_{i=1}^{n} y^{2}{ }_{i}-\left(\sum_{i=1}^{n} y_{i}\right)^{2}\right]}
$$

dimana: $\mathrm{x}$ : tinggi pohon, $\mathrm{y}$ : diameter pohon, $\mathrm{n}=$ jumlah pohon

Walpole (1995) mendifinisikan koefisien korelasi liniar sebagai ukuran hubungan linear antar dua peubah x dan y dan dilambangkan r, Bila nilai $r$ mendekati 1 atau -1, hubungan antara kedua peubah itu kuat dan berarti terdapat korelasi yang tinggi antar keduanya (Walpole, 1995).

Sebaran jumlah pohon menurut kelas diameter dan kelas tinggi bebas cabang dari pohon sampel disusun dalam diagram kumpul (plotting-diagram). Selain sebaran $D b h-H c b$, disusun pula persamaan regresi hubungan $H c b-D b h$. Bentuk model yang disusun adalah:

Persamaan $1 H c b=b_{0}+b_{1} D$

\section{Model persamaan penduga volume pohon}

Muhdin \& Hakim (2004) menyatakan bahwa, tabel volume pohon adalah sebuah tabel yang digunakan untuk menentukan volume kayu pohon berdiri berdasarkan dimensi-dimensi penentu volume (biasanya diameter setinggi dada, tinggi pohon, dan/atau angka bentuk), yang dibuat menggunakan persamaan volume batang melalui analisis regresi. Tabel volume yang dibuat berdasarkan persamaan terbaik yang diperoleh dari tahap penyusunan model, diharapkan juga memberikan nilai dugaan terbaik saat digunakan di lapangan.

Model volume pohon disusun dalam bentuk model matematik yang menghubungkan antara volume batang pohon dengan kulit $(V)$ dengan parameter diameter setinggi dada $(D)$, atau gabungan parameter $D$ dan parameter tinggi pohon $(H)$, yaitu:

$$
\begin{aligned}
& \text { Persamaan } 2 \operatorname{Ln} V=b_{0}+b_{1} \operatorname{Ln} D \\
& \text { (Brandies et al., 2006; } \\
& \text { (Akinnifesi and Akinsami, } \\
& \text { 1995) } \\
& \text { Persamaan } 3 \text { Ln } V=b_{0}+b_{1} \operatorname{Ln} D+b_{2} \operatorname{Ln} H \text {. (3) } \\
& \text { (Akinnifesi and Akinsami, } \\
& \text { 1995) } \\
& \text { Persamaan } 4 V=b_{0} D^{2} H \text {. } \\
& \text { (Spurr,1952) } \\
& \text { Persamaan } 5 V=b_{0}+b_{1} D^{2} H \text {. } \\
& \text { (Zewdie et al., 2012; } \\
& \text { Montagu et al., 2006) }
\end{aligned}
$$

\section{Uji keabsahan model}

Model terpilih harus memenuhi keabsahan persamaan regresi, yaitu semua peubah bebas harus berperan nyata di dalam model, nilai sisaan menyebar normal dan bersifat adiktif serta sebaiknya mempunyai nilai koefisien determinasi terkoreksi $\left(R^{2} a d j\right)$ yang tinggi, sedangkan ketelitian model volume pohon dicerminkan oleh kecilnya simpangan agregatif $(S A)$, dan kecilnya simpangan rata-rata $(S R)$. Chapman dan Meyer (1949) serta Husch et al. (2003) menyatakan bahwa nilai absolut simpangan agregatif model volume pohon sebaiknya tidak melebihi $1 \%$ dan simpangan rata-ratanya tidak lebih dari $10 \%$.

$$
R_{\text {adj }}^{2}=1-\{S S E /(n-1-p)\} /\{S S T /((n-1))\}
$$




$$
\begin{aligned}
& S A=\left(\frac{\sum_{i=2}^{n} V t-\sum_{i=1}^{n} V a}{\sum_{i=1}^{n} V t}\right) \\
& S R=\frac{\left|\sum_{i=2}^{n} V t-\sum_{i=1}^{n} V a\right|}{n} \times 100 \%
\end{aligned}
$$

$n \quad$ : jumlah pohon contoh,

$p$ : jumlah peubah penduga dalam persamaan,

SSE : jumlah kuadrat sisaan,

SST : jumlah kuadrat total $\left(\sum y^{2}\right)$,

$\mathrm{Va}$ : volume pohon aktual,

$V t$ : volume pohon dugaan.

\section{Tolak ukur kesahihan model}

Dalam penelitian model penduga volume ini, model terpilih ditentukan berdasarkan tingkat kesahihan masing-masing model, yaitu tingkat kompatibilitasnya untuk diterapkan pada pohon contoh validasi atau data independen "(independent data)"

Soares et al. (1995), Vanclay dan Skovsgaard (1997), serta Huang et al. (2003) merekomendasikan 4 kriteria perhitungan statistik untuk mengevaluasi kesahihan model, yaitu nilai ratarata sisaan (mean residual: MRES), nilai ratarata sisaan absolut (absolute mean residual: AMRES), akar rata-rata kuadrat sisaan (root mean squared error: RMSE), dan efisiensi model tereduksi (the adjusted model efficency: $M E F_{a d j}$ ).

Persamaan $7 \quad M R E S=\frac{\sum_{i=1}^{n}\left(y_{i}-\hat{y}_{i}\right)}{n}$

Persamaan $8 \quad A M R E S=\frac{\sum_{i=1}^{n}\left|y_{i}-\hat{y}_{i}\right|}{n}$

Persamaan $9 \quad R M S E=\sqrt{\frac{\sum_{i=1}^{n}\left(y_{i}-\hat{y}_{i}\right)^{2}}{n-p}}$

Persamaan 10 MEF adj $=1-\frac{(n-1) \sum_{i=1}^{n}\left(y_{i}-\hat{y}_{i}\right)^{2}}{(n-p) \sum_{i=1}^{n}\left(y_{i}-\bar{y}_{i}\right)^{2} .}$

dimana:

$y_{i}$ : nilai $\mathrm{V}$ dari independent data ( $V$ value of independent data),

$\hat{y}$ : nilai dugaan $\mathrm{V}$ berdasar model (estimated $\mathrm{V}$ value based on each model),

$\bar{y}$ : nilai rata-rata $\mathrm{V}$ dari independent data (me-an $\mathrm{V}$ value of independent data),
$N$ : jumlah data $\mathrm{V}$ dalam independent data (the number of dobh data in independent data),

$P$ : jumlah peubah tidak bergantung dalam model (the number of independent variables in each model).

Selain 4 kriteria di atas, penelitian ini juga mengikuti saran Burnham dan Anderson (1998) yang menggunakan "kriteria informasi Akaike" (Akaike's information criterion: AIC) yang merupakan indeks untuk seleksi model terbaik didasarkan "jarak Kullback-Liebler" (KullbackLiebler distance) minimum.

Persamaan (11) $A I C=n \operatorname{Ln} \hat{\sigma}^{2}+2(p+1)$.

dimana $\hat{\sigma}^{2}=\frac{\sum_{i=1}^{n}\left(y_{i}-\hat{y}_{i}\right)^{2}}{n}$

\section{HASIL DAN PEMBAHASAN}

\section{A. Hubungan Diameter dan Tinggi}

Hubungan antara diameter pohon dengan tinggi pohon adalah untuk menaksir tinggi suatu pohon berdasarkan peubah kuncinya, yaitu diameter pohon. Hal ini dilakukan karena dalam inventarisasi hutan, untuk menduga volume pohon per pohon dalam suatu tegakan hutan diperlukan pengukuran diamater dan atau tinggi pohon. Pengukuran tinggi pohon dalam tegakan hutan merupakan pekerjaan yang sulit dibanding pengukuran diameter pohon dan relatif membutuhkan waktu yang lama serta dapat memberikan kesalahan yang disebabkan bukan karena sampling (non sampling error) yang cukup besar, mengingat dalam inventarisasi hutan jumlah pohon yang diukur cukup banyak dan dalam areal yang luas.

Dari analisis regresi 35 data pohon sampel yang terkumpul, bentuk hubungan antara $\mathrm{Hcb}$ dengan Dbh adalah Persamaan 12.

$\mathrm{T}=9,54+0,0516 \mathrm{D}$

Analisis korelasi digunakan untuk menilai keeratan hubungan antara diameter dan tinggi. Nilai korelasi yang didapat antara diameter dan tinggi $=0,673$ dengan $\mathrm{P}$-Value $=0,00$ sehingga membuktikan adanya hubungan yang kuat antara diameter dan tinggi sedangkan hasil uji keabsahan model pada persamaan 12 menggunakan uji kenormalan dan sebaran sisaan ditunjukan pada gambar 1Adan 1B. 

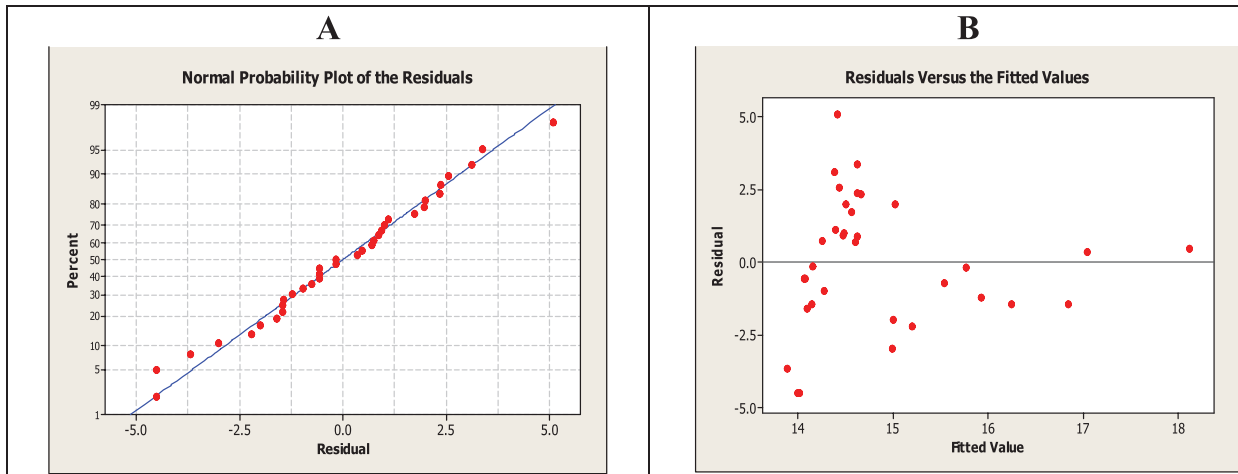

Gambar(Figure) 1. (A) Grafik plot peluang normal dari sisaan Persamaan 12 (Normal probability plot of the residual of Equation 12)

(B) Sisaan dibandingkan nilai dugaan dari Persamaan 12 (Residual versus the fitted values of Equation 12)

Kecermatan hubungan ini mengindikasikan bentuk batang pohon weru yang normal, semakin besar diameter pohon weru akan semakin fungsi batang pokoknya dan akan semakin besar volumenya.

\section{B. Model Penduga Volume Pohon}

Penyusunan model volume pohon weru di
Kabupaten Majalengka dilakukan dengan mencoba menerapkan bentuk-bentuk persamaan dari Persamaan-2 sampai dengan Persamaan-6 dapat di lihat pada Tabel 2 .

Setelah disusun model-model persamaan tabel volume maka dilanjutkan dengan uji kenormalan sisaan serta keaditifan terlihat pada Gambar 2 sampai 6.

Tabel(Table)2. Performasi model-model penduga volume pohon jenis weru (Performance of tree volume model of weru)

\begin{tabular}{cccccc}
\hline Persamaan & Intersep & \multicolumn{2}{c}{ Koefisien regresi (Regression coefficients) } & \multirow{2}{*}{$R_{\text {adj }}^{2}$} \\
\cline { 3 - 5 }$($ Equation $)$ & $($ Intercept $)$ & $b_{1}$ & $b_{2}$ & $b_{3}$ & \\
\hline 2 & $-7,59$ & 2,02 & - & - & 0,993 \\
3 & $-8,46$ & 1,89 & 0,537 & - & 0,996 \\
4 & 0,000038 & - & - & - & 0,994 \\
5 & 0,0949 & 0,000037 & - & - & 0,998 \\
6 & $-0,115$ & 0,000026 & 0,000157 & 0,0168 & 0,998 \\
\hline
\end{tabular}

Keterangan (Remarks): ns: tidak nyata (not significant)

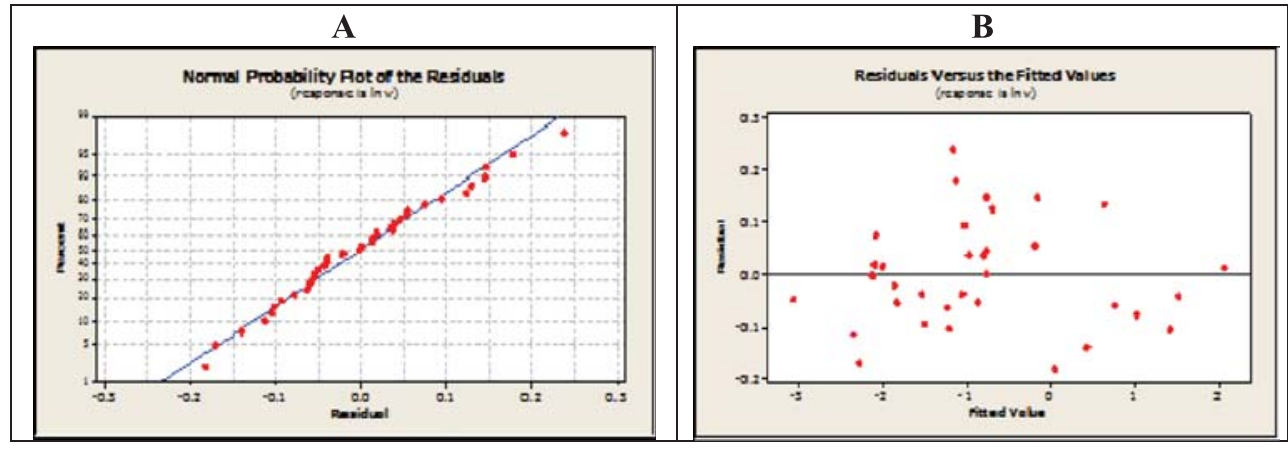

Gambar (Figure)2. (A) Grafik plot peluang normal dari sisaan Persamaan 2 (Normal probability plot of the residual of Equation 2)

(B) Sisaan dibandingkan nilai dugaan dari Persamaan 2 (Residual versus the fitted values of Equation 2) 

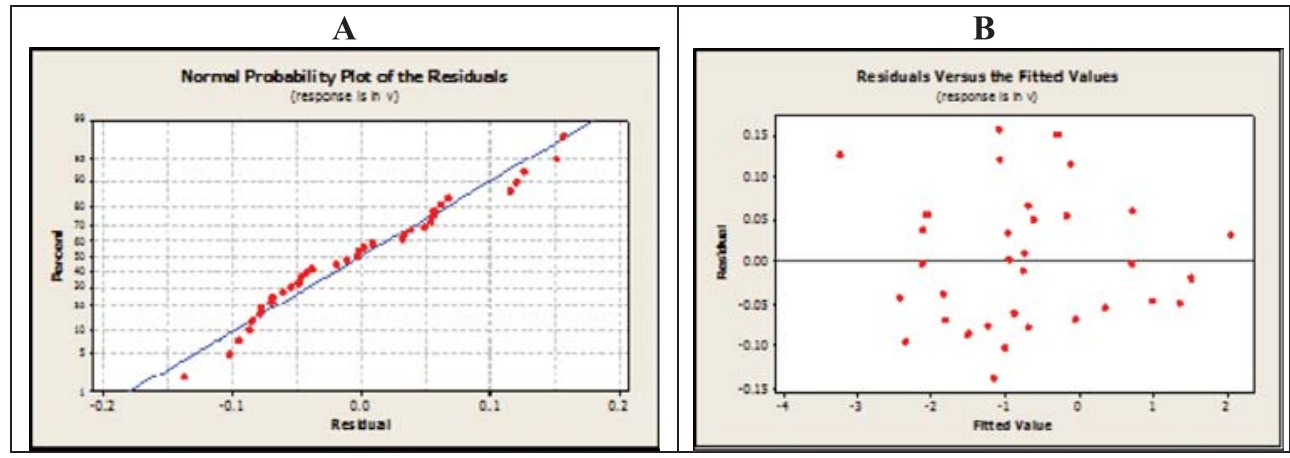

Gambar(Figure) 3. (A) Grafik plot peluang normal dari sisaan Persamaan 3 (Normal probability plot of the residual of Equation 3 )

(B) Sisaan dibandingkan nilai dugaan dari Persamaan 3 (Residual versus the fitted values of Equation 3)
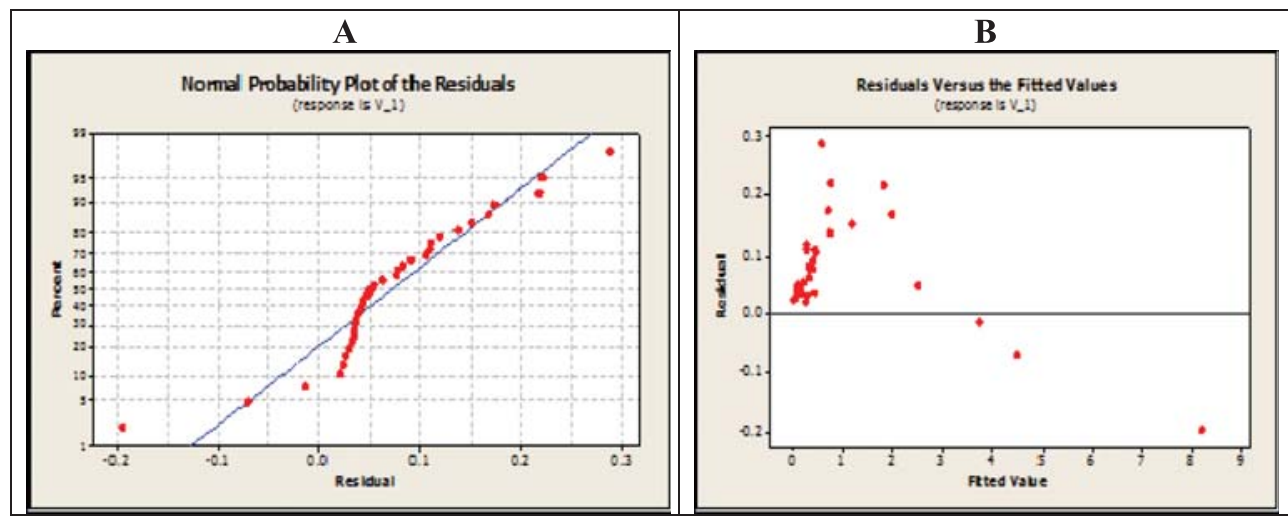

Gambar(Figure) 4. (A) Grafik plot peluang normal dari sisaan Persamaan 4 (Normal probability plot of the residual of Equation 4)

(B) Sisaan dibandingkan nilai dugaan dari Persamaan 4 (Residual versus the fitted values of Equation 4)
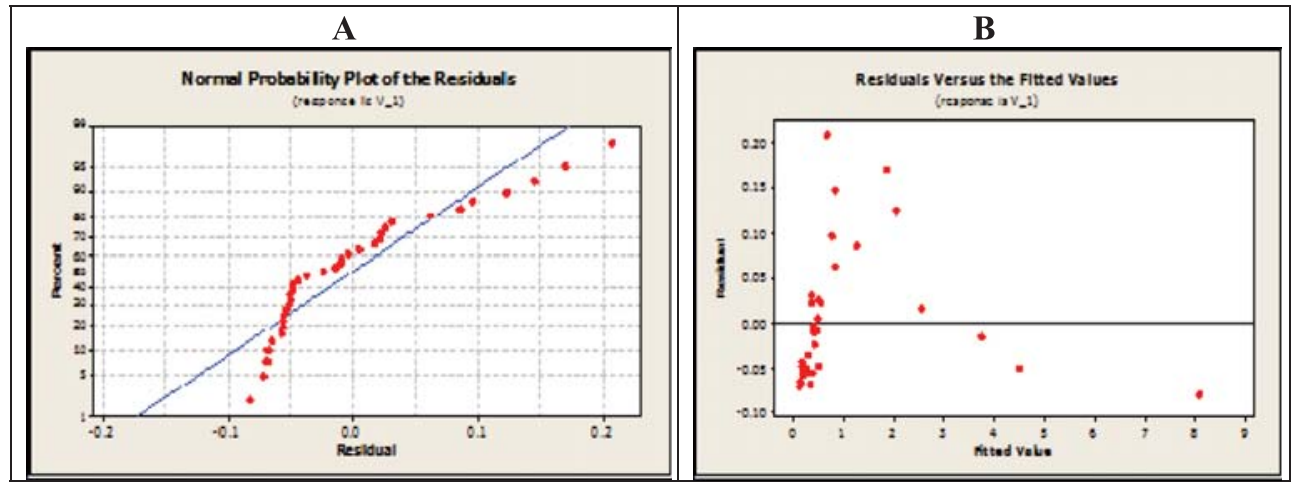

Gambar(Figure) 5. (A) Grafik plot peluang normal dari sisaan Persamaan 5 (Normal probability plot of the residual of Equation 5)

(B) Sisaan dibandingkan nilai dugaan dari Persamaan 5 (Residual versus the fitted values of Equation 5) 

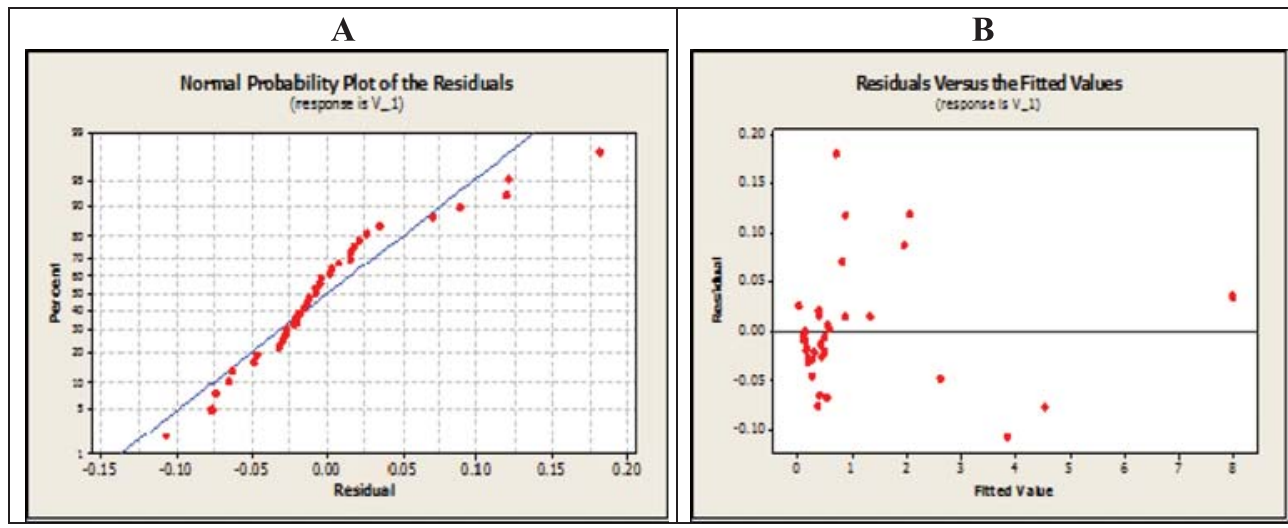

Gambar(Figure) 6. (A) Grafik plot peluang normal dari sisaan Persamaan 6 (Normal probability plot of the residual of Equation 6)

(B) Sisaan dibandingkan nilai dugaan dari Persamaan 6 (Residual versus the fitted values of Equation 6)

Dari hasil pengujian kenormalan sisaan dan keaditifan dari model penduga volume pada Gambar 2 sampai 6, terlihat persamaan 2 dan 3 yang lebih memenuhi sifat kenormalan sisaan, terlihat dari grafik plot hubungan antara sisaan dengan kemungkinan normal sisaan yang cenderung membentuk garis linear dan melewati titik pusat sumbu $(0,0)$, sehingga dapat disimpulkan bahwa 2 model tersebut memiliki sisaan yang cukup menyebar normal.

\section{Uji Ketelitian Model}

Dengan didasarkan pada 12 "pohon independen" (Independent data) karena yang memenuhi uji kenormalan sisaan dan keaditifan persamaan 2 dan 3 maka model terpilih harus memenuhin keabsahan persamaan regresi dapat dilihat pada table 3 .

Peubah diameter dan peubah tinggi sebagai peubah tunggal ataupun ganda mendapatkan nilai koefosien determinasi yang besar $\left(\mathrm{R}^{2}>80\right.$.
Koefisien Determinasi yang dihasilkan pada persamaan 2 dan 3 mencapai $90 \%$. Nilai SA dan SR yang kecil sehingga dua persamaan tersebut dapat digunakan.

\section{Pemilihan Model}

Hasil perhitungan MRES (rata-rata sisaan), AMRES (rata-rata sisaan absolut), RMSE (akar rata-rata kuadrat sisaan), $M E F_{a d j}$ (efisiensi model tereduksi), dan $A I C$ (kriteria informasi Akaike) dari dua persamaan yang memiliki ketelitian dirangkum dalam Tabel 4.

Dalam Tabel 4 terlihat bahwa bentuk Persamaan 2 mempunyai total skor paling kecil, sehingga didasarkan tolok ukur MRES, AMRES, $R M S E, A I C$, dan $M E F_{a d j}$, persamaan tersebut terpilih sebagai model tabel volume lokal jenis weru di Majalengka.

Bentuk lengkap model penduga volume pohon tersebut adalah Persamaan 2.

$\mathrm{Ln} \mathrm{V}=-7,59+2,02 \ln \mathrm{D}$

Tabel (Table) 3. Nilai SA, SR dan $R_{a d j}$ pada masing-masing bentuk model volume (The values of SA, SR and $R_{\text {adj }}$, of each volume model)

\begin{tabular}{rccc}
\hline $\begin{array}{c}\text { Persamaan } \\
\text { (Equation) }\end{array}$ & SA & SR & $R_{\text {adj }}$ \\
(Agregative deviation) & (Relative deviation) & $\begin{array}{c}\text { (coeffocient of adjusted } \\
\text { determination) }\end{array}$ \\
\hline 2 & 0,0165 & 0,1178 & 99,3 \\
3 & 0,0983 & 0,7022 & 99,6 \\
\hline
\end{tabular}


Dari hasil persamaan tersebut maka akan menghasilkan tabel volume lokal yang bisa langsung dimanfaatkan oleh petani. Hasil tabel ditunjukan pada lampiran 1 .

\section{KESIMPULAN DAN SARAN}

Dari hasil penelitian ini dapat disimpulkan :

1. Penduga volume pohon jenis weru menggunakan satu peubah bebas yaitu diameter atau mempunyai tingkat akurasi yang lebih tinggi dibandingkan model penduga yang menggunakan diameter dan tinggi sebagai peubah bebasnya.

2. Model Penduga pohon jenis Weru adalah menggunakan peubah bebas tunggal yaitu diameter dengan persamaan $\mathrm{Ln} \mathrm{V}=-7,59+$ 2,02 ln D dengan nilai SA 0,0165 dan SR 0,1178 .

\section{DAFTAR PUSTAKA}

Abdurahman, Maman, Muhidin, Sambas, \& Somantri, Ating. (2012). Dasar-Dasar Metode Statistika Untuk Penelitian. Bandung: CV. Pustaka Setia.

Akinnifesi, F.K., \& Akinsami, F.A. 1995. Linear equation for estimating the merchantable wood volume of Gmelina arborea in Southwest Nigeria. Journal of Tripical Science. Volume 7 No.3:391 - 397.

Arevalo, C.B.M., Volk, T.A., Bevilacqua, E., \& Abrahamson, L. (2007). Development and validasition of aboveground biomassa estimation for four salix clones in central New York. Biomass and Bioenergy 31 : 1-12

Badan Pusat Statistik Kabupaten Majalengka. (2011). Kecamatan Majalengka dalam Angka Tahun 2010. Majalengka.

Brandies,T.J., Delaney, M.D., Parresol, B.R., \& Royer, L. (2006). Development of equation for predicting puerto rican subtripical dry forest biomass and volume. Forest Ecology and Management 233, 133-142.

Burnham, K.P., \& Anderson, D.J. (1998). Model selection and inference: a practical information - theoritic approach. In: Springer, Berlin, Carvalho, (S.P.C.), Mendonca, A.R., Lima, M. P., \& Calegario, N. 2010. Diferentes estrategias para estimar o volume commercial de Anadenanthera colubrine (Vell) Brenan. Cerne Lavras v. 16, n. 3: 399-406. Accessed on June
24, 2013, dari http://www.dcf.ufla.br/cerne/ artigos/25-10-20101868v16_n3_artigo\%2016.pdf.

Chapman, H.H., \& Meyer, W.H. (1949). Forest Mensuration. McGraw-Hill Book Company, Inc, New york.

Huang, S., Yang, Y., \& Wang, Y. 2003. A critical look at procedures for validating growth and yield models. In: Amaro, A., D. Reed, \& P. Soares. (Eds.). Modelling Forest Systems. CAB International, Wallingford, pp. 271-293.

Husch, B., Beers, T.W., Kershaw, J.A. (2003). Forest Mensuration. New Jersey: John Wiley and Sons Inc.

Jarunadi. (2013). Pengelolaan kesuburan tanah. Akses tanggal 23 Januari 2013. dari http:// uwityangyoyo. files.wordpress.com/2012/03/ jarunadi-belum. doc.

Muhdin, \& A.R. Hakim. (2004). Penentuan jumlah pohon contoh minimal untuk penyusunan persamaan volume melalui fungsi taper : Studi kasus pada jenis Pinus merkusii jungh et de vriese di Hutan Pendidikan Gunung Walat, Sukabumi, Jawa Barat. Jurnal Manajemen Hutan Tropika Vol. XNo. 2:22-31

Montagu, K.D., Duttmer, K., Barton, C.V.M., \& Cownie, A.L. (2005). Developing general allometric relationships for regional estimates of carbon sequestration example using Eucalyptus pilularis from seven contrasting site. Forest Ecology and Management 204: 113-127.

Orwa et al. (2009) Albizia amara botanical information. Agro-forestry Database 4.0.

Romancier, R.M. (1961). Weight and volume of plantation-grown loblolly pine. USDA Forest Services. RN-161.

Bustomi, S. (2010). Pengelolaan Hutan Tanaman Kayu Energi. RPI 2010 - 2014. Pusat Penelitian dan Pengembangan Hasil Hutan. 345 - 349.

Soares, P., Tome, M., Skovsgaard, J.P., \& Vanclay, J.K. (1995). Evaluating a growth model for forest management using continous forest inventory data. For. Ecol. Manage. 71:251-265.

Spurr, S.H. 1952 . Forest inventory. New York: The Ronald Press Company.

Vanclay, J.K., \& Skovsgaard, J.P. (1997). Evaluating forest growth models. Ecol. Model. 98: 7-42.

Walpole, R.E. (1995). Pengantar statistik. Edisi 3. Sumantri, B., (Penerjemah); Jakarta: Gramedia. Terjemahan dari Introduction to statistics $3^{r d}$ edition 
Zewdie, M., Muukkonen, P., Makipaa, R., \& Mencuccini, M. (2005). Biomass and stem volume equation for tree species in Europe.
Silva Fennica Monographs 4. The Finish Forest Research Institute. 


\section{Lampiran (Appendix) 1.}

Tabel volume lokal jenis weru di Kabupaten Majalengka dengan persamaan (Local volume table of weru in Majalengka District with equation):

$$
\operatorname{Ln} \mathrm{V}=-7,59+2,02 \ln \mathrm{D})
$$

\begin{tabular}{|l|l|}
\hline $\mathrm{D}$ & $\mathrm{V}$ \\
\hline$(\mathrm{cm})$ & $\left(\mathrm{m}^{3}\right)$ \\
\hline 9 & 0,0427833 \\
\hline 9,5 & 0,0477207 \\
\hline 10 & 0,0529304 \\
\hline 10,5 & 0,0584127 \\
\hline 11 & 0,0641679 \\
\hline 11,5 & 0,0701963 \\
\hline 12 & 0,0764982 \\
\hline 12,5 & 0,0830736 \\
\hline 13 & 0,0899229 \\
\hline 13,5 & 0,0970463 \\
\hline 14 & 0,104444 \\
\hline 14,5 & 0,1121162 \\
\hline 15 & 0.120063 \\
\hline 15,5 & 0,1282847 \\
\hline 16 & 0,1367815 \\
\hline 16,5 & 0,1455534 \\
\hline 17 & 0,1546008 \\
\hline 17,5 & 0,1639237 \\
\hline 18 & 0,1735223 \\
\hline 18,5 & 0,1833968 \\
\hline 19 & 0,1935473 \\
\hline 19,5 & 0,203974 \\
\hline 20 & 0,214677 \\
\hline 20,5 & 0,2256564 \\
\hline 21 & 0,2369124 \\
\hline 21,5 & 0,2484452 \\
\hline 22 & 0,2602548 \\
\hline 22,5 & 0,2723413 \\
\hline 23 & 0,284705 \\
\hline 23,5 & 0,2973459 \\
\hline 24 & 0,3102641 \\
\hline 24,5 & 0,3234598 \\
\hline 25 & 0,3369331 \\
\hline 25,5 & 0,3506841 \\
\hline 26 & 0,3647128 \\
\hline 26,5 & 0,3790195 \\
\hline 27 & 0,3936042 \\
\hline 27,5 & 0,408467 \\
\hline 28 & 0,423608 \\
\hline 28.5 & 0,4390273 \\
\hline 30 & 0.454725 \\
\hline 30.5 & 0,4707013 \\
\hline 31 & 0,52030296961 \\
\hline
\end{tabular}

\begin{tabular}{|c|c|}
\hline D & V \\
\hline (cm) & $\left(\mathrm{m}^{3}\right)$ \\
\hline 31,5 & 0,5373932 \\
\hline 32 & 0,5547634 \\
\hline 32,5 & 0,5724127 \\
\hline 33 & 0,5903411 \\
\hline 33,5 & 0,6085488 \\
\hline 34 & 0,6270357 \\
\hline 34,5 & 0,6458021 \\
\hline 35 & 0,6648479 \\
\hline 35,5 & 0,6841734 \\
\hline 36 & 0,7037784 \\
\hline 36,5 & 0,7236632 \\
\hline 37 & 0,7438277 \\
\hline 37.5 & 0,7642722 \\
\hline 38 & 0,7849965 \\
\hline 38.5 & 0,806001 \\
\hline 39 & 0,8272855 \\
\hline 39.5 & 0,8488501 \\
\hline 40 & 0,870695 \\
\hline 40.5 & 0,8928202 \\
\hline 41 & 0,9152258 \\
\hline 41.5 & 0,9379119 \\
\hline 42 & 0,9608784 \\
\hline 42,5 & 0,9841256 \\
\hline 43 & 1,0076534 \\
\hline 43,5 & 1,0314619 \\
\hline 44 & 1,0555512 \\
\hline 44,5 & 1,0799213 \\
\hline 45 & 1,1045723 \\
\hline 45,5 & 1,1295043 \\
\hline 46 & 1,1547174 \\
\hline 46,5 & 1,1802115 \\
\hline 47 & 1,2059868 \\
\hline 47,5 & 1,2320433 \\
\hline 48 & 1,2583811 \\
\hline 48,5 & 1,2850002 \\
\hline 49 & 1,3119007 \\
\hline 49,5 & 1,3390827 \\
\hline 50 & 1,3665461 \\
\hline 50,5 & 1,3942911 \\
\hline 51 & 1,4223178 \\
\hline 51.5 & 1,4506261 \\
\hline 52 & 1,4792161 \\
\hline 52,5 & 1,508088 \\
\hline 53 & 1,5372416 \\
\hline 53,5 & 1,5666772 \\
\hline
\end{tabular}

\begin{tabular}{|c|c|}
\hline D & $\mathrm{V}$ \\
\hline$(\mathrm{cm})$ & $\left(\mathrm{m}^{3}\right)$ \\
\hline 54 & 1,5963947 \\
\hline 54.5 & 1,6263942 \\
\hline 55 & 1,6566757 \\
\hline 55.5 & 1,6872394 \\
\hline 56 & 1,7180852 \\
\hline 56.5 & 1,7492132 \\
\hline 57 & 1,7806235 \\
\hline 57.5 & 1,812316 \\
\hline 58 & 1,8442909 \\
\hline 58.5 & 1,8765482 \\
\hline 59 & 1,909088 \\
\hline 59.5 & 1,9419102 \\
\hline 60 & 1,975015 \\
\hline 60.5 & 2,0084024 \\
\hline 61 & 2,0420725 \\
\hline 61.5 & 2,0760252 \\
\hline 62 & 2,1102606 \\
\hline 62.5 & 2,1447788 \\
\hline 63 & 2,1795799 \\
\hline 63.5 & 2,2146638 \\
\hline 64 & 2,2500306 \\
\hline 64.5 & 2,2856804 \\
\hline 65 & 2,3216132 \\
\hline 65.5 & 2,357829 \\
\hline 66 & 2,3943279 \\
\hline 66.5 & 2,43111 \\
\hline 67 & 2,4681752 \\
\hline 67.5 & 2,5055236 \\
\hline 68 & 2,5431553 \\
\hline 68.5 & 2,5810703 \\
\hline 69 & 2,6192687 \\
\hline 69.5 & 2,6577504 \\
\hline 70 & 2,6965155 \\
\hline 70.5 & 2,7355641 \\
\hline 71 & 2,7748962 \\
\hline 71.5 & 2,8145119 \\
\hline 72 & 2,8544111 \\
\hline 72.5 & 2,894594 \\
\hline 73 & 2,9350605 \\
\hline 73.5 & 2,9758107 \\
\hline 74 & 3,0168447 \\
\hline 74.5 & 3,0581625 \\
\hline 75 & 3,099764 \\
\hline 75.5 & 3,1416495 \\
\hline 76 & 3,1838188 \\
\hline
\end{tabular}

\begin{tabular}{|l|l|}
\hline $\mathrm{D}$ & \multicolumn{1}{|c|}{$\mathrm{V}$} \\
\hline$(\mathrm{cm})$ & $\left(\mathrm{m}^{3}\right)$ \\
\hline 76,5 & 3,226272 \\
\hline 77 & 3,2690092 \\
\hline 77,5 & 3,3120305 \\
\hline 78 & 3,3553357 \\
\hline 78,5 & 3,3989251 \\
\hline 79 & 3,4427985 \\
\hline 79,5 & 3,4869561 \\
\hline 80 & 3,5313979 \\
\hline 80,5 & 3,5761239 \\
\hline 81 & 3,6211342 \\
\hline 81,5 & 3,6664288 \\
\hline 82 & 3,7120077 \\
\hline 82,5 & 3,7578709 \\
\hline 83 & 3.8040186 \\
\hline 83,5 & 3,8504507 \\
\hline 84 & 3,8971672 \\
\hline 84,5 & 3,9441683 \\
\hline 85 & 3,9914539 \\
\hline 85,5 & 4,039024 \\
\hline 86 & 4,0868788 \\
\hline 86,5 & 4,1350181 \\
\hline 87 & 4,1834422 \\
\hline 87,5 & 4,2321509 \\
\hline 88 & 4,2811444 \\
\hline 88,5 & 4,3304227 \\
\hline 89 & 4,3799857 \\
\hline 89,5 & 4,4298336 \\
\hline 90 & 4,4799663 \\
\hline 90,5 & 4,530384 \\
\hline 91 & 4,5810865 \\
\hline 91,5 & 4,632074 \\
\hline 92 & 4,6833465 \\
\hline 92,5 & 4,734904 \\
\hline 93 & 4,7867466 \\
\hline 93,5 & 4,8388743 \\
\hline 94 & 4,891287 \\
\hline 94,5 & 4,9439849 \\
\hline 95 & 4,996968 \\
\hline 95,5 & 5,0502362 \\
\hline 96 & 5,1037897 \\
\hline 97,5 & 5,1576285 \\
\hline 98,5117525 \\
\hline & 5,32085666 \\
\hline & \\
\hline 9758367 \\
\hline 9
\end{tabular}

\begin{tabular}{|c|c|}
\hline $\mathrm{D}$ & $\mathrm{V}$ \\
\hline$(\mathrm{cm})$ & $\left(\mathrm{m}^{3}\right)$ \\
\hline 99 & 5,4311022 \\
\hline 99,5 & 5,4866531 \\
\hline 100 & 5,5424895 \\
\hline 100,5 & 5,5986114 \\
\hline 101 & 5,6550189 \\
\hline 101,5 & 5,7117118 \\
\hline 102 & 5,7686904 \\
\hline 102,5 & 5,8259545 \\
\hline 103 & 5,8835043 \\
\hline 103,5 & 5.9413398 \\
\hline 104 & 5,9994609 \\
\hline 104,5 & 6,0578678 \\
\hline 105 & 6,1165604 \\
\hline 105,5 & 6,1755387 \\
\hline 106 & 6,2348029 \\
\hline 106,5 & 6,2943529 \\
\hline 107 & 6,3541888 \\
\hline 107,5 & 6,4143105 \\
\hline 108 & 6,4747182 \\
\hline 108,5 & 6,5354117 \\
\hline 109 & 6,5963913 \\
\hline 109,5 & 6,6576568 \\
\hline 110 & 6,7192083 \\
\hline 110,5 & 6,7810459 \\
\hline 111 & 6,8431695 \\
\hline 111,5 & 6,9055793 \\
\hline 112 & 6,9682751 \\
\hline 112,5 & 7,0312571 \\
\hline 113 & 7,0945252 \\
\hline
\end{tabular}

